ACTA AGROBOTANICA

Vol. 62 (2): 117-123

2009

\title{
THE ESTIMATION OF FUNGAL SPORE CONCENTRATIONS USING TWO COUNTING METHODS
}

\author{
${ }^{1}$ Danuta Stępalska, ${ }^{2}$ Jerzy Wołek \\ ${ }^{1}$ Institute of Botany, Jagiellonian University, 31-501 Cracow, Kopernika 27, Poland \\ e-mail: stepalska@op.pl \\ ${ }^{2}$ Institute of Biology; Pedagogical University of Cracow, Podbrzezie 3, Cracow, Poland
}

Received: 20.08 .2009

\section{Abstract}

The aim of the study was to estimate the spore counts of Alternaria and Cladosporium using the single longitudinal traverse and twelve transverse traverses methods. Both the single and twelve traverses methods generally showed similar average daily concentration fluctuations of the two studied spore types on the same days, although the single traverse method usually presented higher spore concentrations. However, analysing the distribution of concentrations obtained using both methods, there were days when the single or twelve traverses method showed a rise or fall in concentration which was not reflected by the other method. In case of Cladosporium higher daily concentrations obtained using the twelve traverses method occurred more frequently in the months of the highest spore concentrations. The higher concentrations of Alternaria spores obtained using this method occurred more frequently in the months of the lowest concentrations. Analysis of correlation (Pearson's correlation coefficient $r$ ) between those variables (number of days with higher concentration and monthly concentration) showed that the correlation was significant for Cladosporium and not significant for Alternaria, for both at the significance level $\alpha=0.05$. The results of the Wilcoxon's Paired Sample Test indicated that for both taxa the average daily concentrations obtained using the 1 traverse method were significantly higher than those obtained using the 12 traverses method.

Key words: aerobiology, Cladosporium, Alternaria, spores, methods of counting, statistical analysis, Cracow, Poland

\section{INTRODUCTION}

One of the main aims of aerobiological monitoring is to define daily pollen and fungal spore concentrations. The most precise method which would allow to obtain these values is spore counting on the whole surface of a daily section of the Melinex tape. However, this method takes much time and does not increase in precision considerably. In consequence, only a small part of the tape daily section is analysed. The majority of aerobiologists apply one of the four methods of counting: in 12 transverse traverses of the daily section, in horizontal continuous traverses (3-5), in separate fields of horizontal traverses and random method (A i r b o r n e ... 1994).

We never know the whole taxonomic composition of organisms in the analysed air volume. Knowledge of the biological content of the air refers to a small part of observations which do not reflect the real state of the atmosphere, irrespective of the methods applied to estimate fungal spore concentrations ( $\mathrm{Co} \mathrm{m}$ to is, A l c a z a r and Neron, 1999). Because analysis of the whole sample of the air during the day and night requires much time, there were studies how to solve the problem and find the method which would allow to reduce analysis time without loss in counting precision. The proposed methods assumed a regular distribution of particles in the analysed air sample. The different methods of counting of pollen grains and fungal spores daily and hourly, applied by aerobiologists, triggered discussion on precision and efficiency of the proposed methods. The majority of studies estimating the methods refer mainly to pollen (Käpylä and Penttinen, 1981; Molina, Rodriguez and Palacios, 1996; C a rinanos et al. 2000). Only a few studies looked for an optimum procedure to count fungal spores (Sterling, Rogers and Levetin, 1999; P e s s i , 2003).

The aim of the study was to estimate daily spore concentrations of Alternaria and Cladosporium obtained by using two different counting methods.

\section{MATERIALS AND METHODS}

The estimation of two different counting methods was performed on the basis of data collected in Cracow in 1997-1999. The study was carried out 
using a Burkard volumetric spore trap of the Hirst design (Hirst, 1952). Spores were counted in 12 transverse traverses (12 traverses) and counting was repeated in 1 horizontal, central traverse (1 traverse). The values of average daily spore concentrations were expressed as spores per cubic metre of air. These values referred to Alternaria and Cladosporium spores occurring in high numbers in June, July, August and September in 1997-1999. Analysis of concentrations calculated by using two methods was performed separately for each type of spores and for each season. Pearson's correlation coefficient (r) was applied to find whether there was a statistical relationship between the monthly spore sum and the number of cases when the 12 traverses method showed higher concentration. To find whether the differences between the concentration values obtained using the two methods were statistically significant, the non-parametric Wilcoxon's Paired Sample Test (one-sided test) was applied. Statistical analysis was performed using the Statistica program version 5.1 (StatSoft, Inc. 1997).

\section{RESULTS}

The results obtained using two different counting methods indicated parallel fluctuations of daily fungal spore concentrations on the same days (for each type of spores), although the values obtained by the 1 traverse method were usually higher than the values obtained by the 12 traverses method (Figs 1,2). Analysing the diurnal periodicity of spore concentrations, some differences between the concentrations obtained using the two methods were observed. A clear increase in concentration of Cladosporium spores was found on the $14^{\text {th }}$ and $16^{\text {th }}$ of June, $7^{\text {th }}$ and $11^{\text {th }}$ of July, and on the $15^{\text {th }}$ and $17^{\text {th }}$ of August in 1997 using the 1 traverse method. This was accompanied by a decrease in concentration calculated using the 12 traverses method. Contrary, on the $18^{\text {th }}$ of June and $10^{\text {th }}, 14^{\text {th }}$ and $16^{\text {th }}$ of August, a decline in concentration was noted using the 1 traverse method, while the results of the 12 traverses method showed an increase in spore concentration (Fig. 1).

Table 1

Results of the Wilcoxon's Paired Sample Test (one-sided test).

\begin{tabular}{cccc}
\hline taxon/season & $\mathrm{n}$ & & Significant difference \\
\hline Alternaria 1997 & 122 & 7,3 & $*$ \\
\hline Alternaria 1998 & 122 & 5,8 & $*$ \\
\hline Alternaria 1999 & 122 & $*, 0$ & $*$ \\
\hline Alternaria $1997-1999$ & 366 & 13,2 & $*$ \\
\hline Cladosporium 1997 & 122 & 9,0 & $*$ \\
\hline Cladosporium 1998 & 122 & & $*$ \\
\hline Cladosporium 1999 & 366 & 4,9 & $*$ \\
\hline
\end{tabular}

$*$ significant difference at significance level $\alpha=0.025$ 

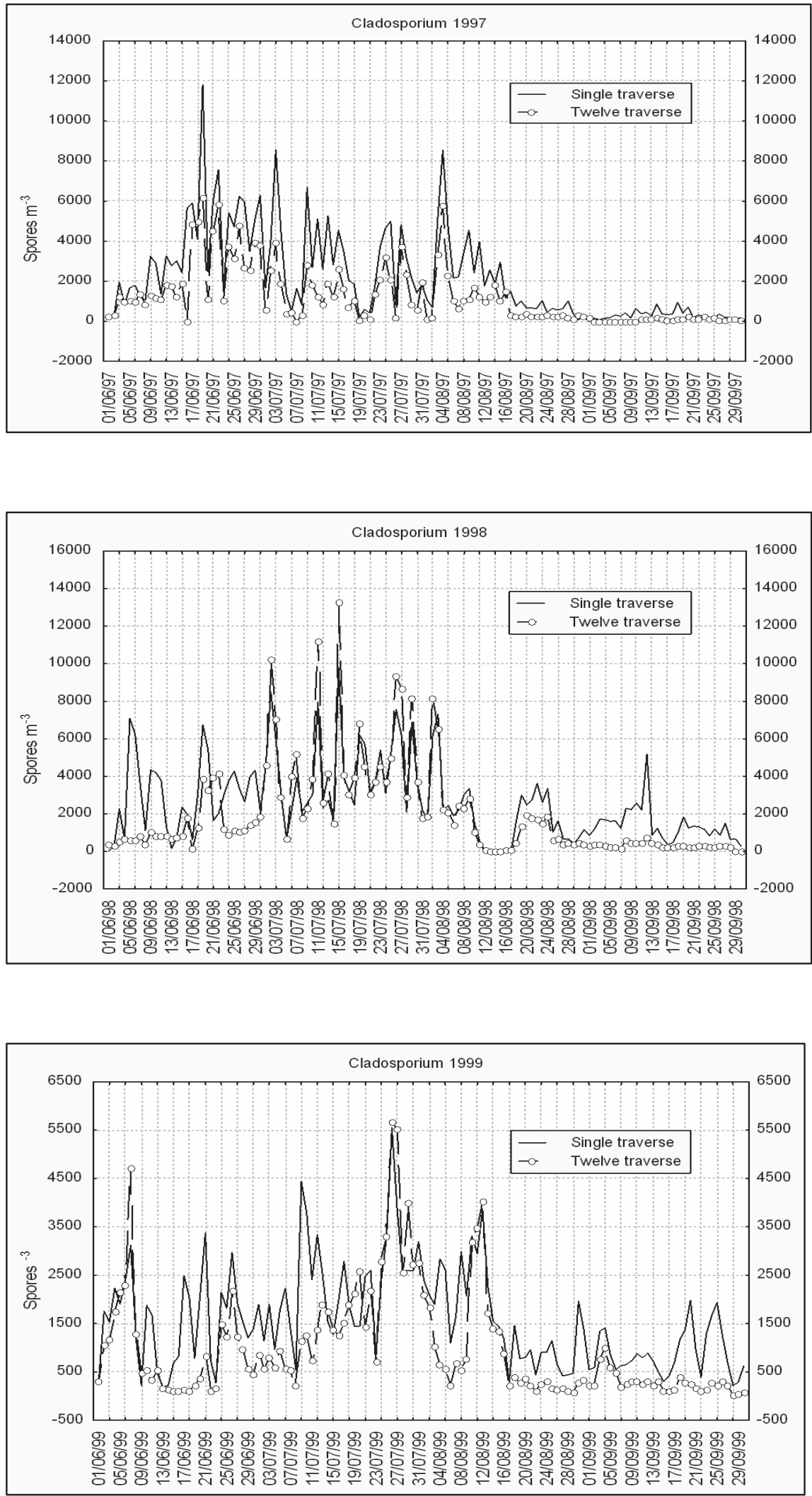

Fig. 1. Average daily concentrations of Cladosporium spores in the Cracow atmosphere during June, July, August and September in 1997-1999. 

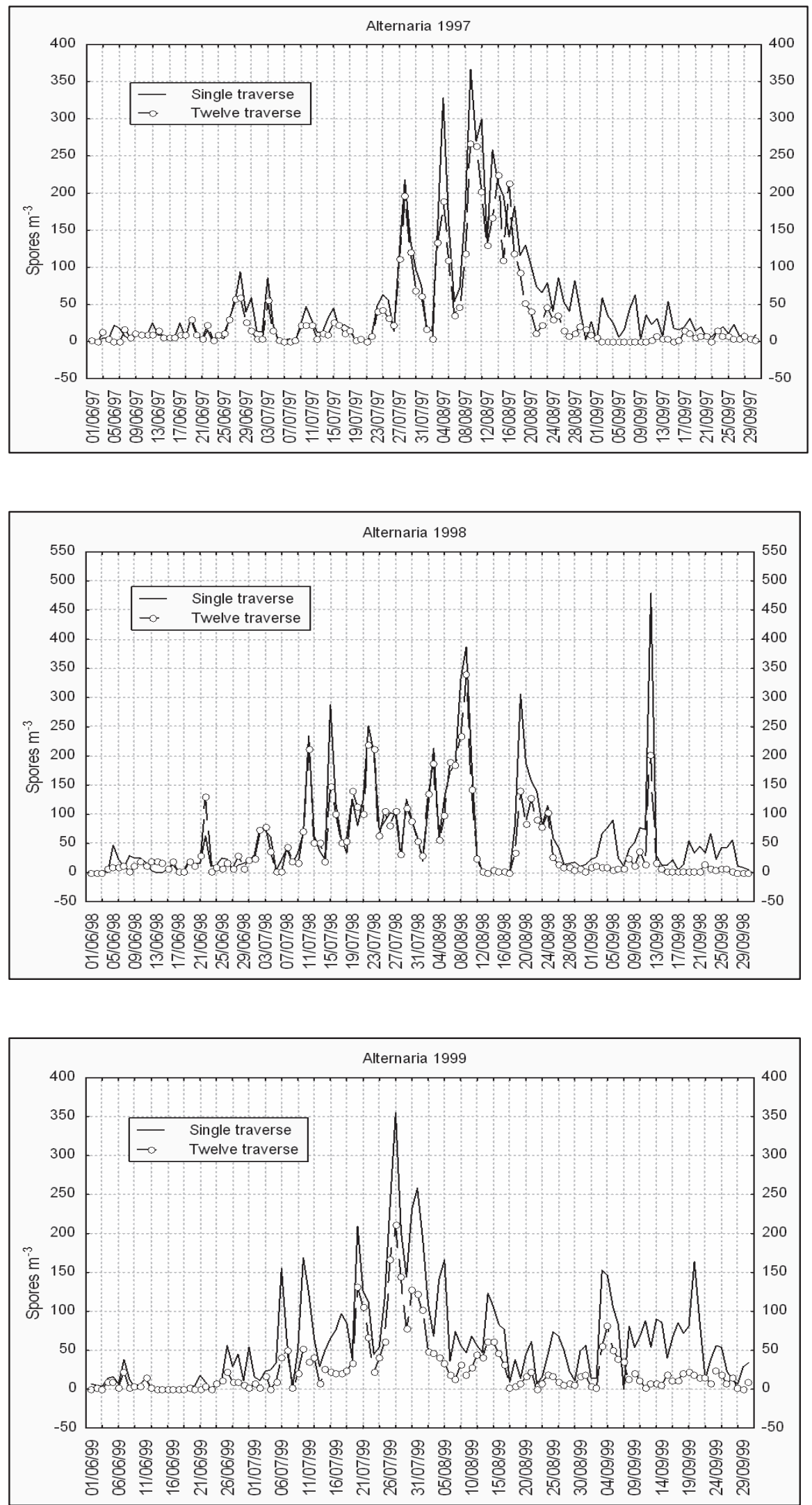

Fig. 2. Average daily concentrations of Alternaria spores in the Cracow atmosphere during June, July, August and September in 1997-1999. 
A similar situation was observed in 1998 when on the $23^{\text {rd }}$ of June an increase in concentration using the 1 traverse method was noted, which coincided with a decrease in concentration calculated by the 12 traverses method. However, on the $21^{\text {st }}$ and $30^{\text {th }}$ of June and $20^{\text {th }}$ of August, an increase in concentration using the 12 traverses method was observed, with a simultaneous decline in concentration obtained by using the 1 traverse method.

Also in 1999 on the $21^{\text {st }}$ of July and $4^{\text {th }}$ of August, an increase in spore concentration using the 1 traverse method was found with a concurrent decrease in concentration calculated by the 12 traverses method. On the $18^{\text {th }}$ and $19^{\text {th }}$ of July, and on the $11^{\text {th }}$ of August, a decrease in concentration using the 1 transverse method was observed and during the same days an increase in concentration calculated by the 12 traverses method was found.

Alternaria spores showed similar fluctuations of concentrations calculated by both methods. In 1997 on the $5^{\text {th }}$ and $30^{\text {th }}$ of June, and $17^{\text {th }}$ of July, an increase in concentration obtained using the 1 traverse method was observed, while a decrease occurred on the same days when applying the 12 traverses method. However, on the $16^{\text {th }}$ of August a decline in concentration calculated by the 1 traverse method and an increase in concentration calculated by the 12 traverses method could be seen (Fig. 2).

In 1998 on the $12^{\text {th }}$ of June, a clear decline in concentration obtained using the 1 traverse method and an increase in concentration calculated by the 12 traverses method occurred on the same days.

In 1999, the last year of the investigation, on the $4^{\text {th }}$ of July, $4^{\text {th }}$ of August, and $8^{\text {th }}$ and $16^{\text {th }}$ of September, an increase in concentration obtained using the 1 traverse method and a decline in concentration calculated by the 12 traverses method were noted on the same days. However, on the $7^{\text {th }}$ and $19^{\text {th }}$ of July, $8^{\text {th }}$ of August and $15^{\text {th }}$ of September, a decrease in concentration using the 1 traverse method and an increase using the 12 traverses method were observed on the same days.

Although generally there occurred higher daily spore concentrations calculated by the 1 traverse method, there were days when the 12 traverses method showed higher values. In case of Cladosporium spores, higher daily concentrations obtained using the 12 traverses method occurred more often in the months of the highest concentrations. In the months of the lowest concentration, almost always the values obtained using the 1 traverse method were higher than the values calculated by the 12 traverses method. In case of Alternaria spores, higher concentrations calculated by the 12 traverses method occurred more often in the months of the lowest concentrations.

To find whether there was a statistical relationship between the monthly spore sum and the number of cases when the 12 traverses method gave higher con- centrations, Pearson's correlation coefficient (r) was calculated. In case of Cladosporium, the correlation between the studied variables was statistically significant at the significance level $\alpha=0.05(\mathrm{r}=0.68 ; \mathrm{n}=$ 12 pairs of results; $t=2.95$ ). For Alternaria, the correlation between the variables in question was non significant at the significance level $\alpha=0.05(\mathrm{r}=-0.31$; $n=12$ pairs of results; $t=-1.034$ ). These results indicated that the number of cases, where the 12 traverses method gave the higher concentration, increased when concentrations were very high, e.g. in Cladosporium spores. Reasonably high concentrations of Alternaria spores did not produce such a correlation.

To find whether the differences between the concentrations obtained using the two methods were statistically significant, the non-parametric Wilcoxon's Paired Sample Test was applied (Tab. 1). The significant differences were obtained at the significance level $\alpha=0.025$ for each type of the studied spores, each season and for the combined 3-year period. The results indicated that for both Alternaria and Cladosporium daily spore concentrations calculated by the 1 traverse method were significantly higher than those calculated by the 12 traverses method.

It must be remembered that in order to estimate the efficiency and precision of both methods it is necessary to compare daily concentrations obtained using both methods to the concentration calculated on the whole surface of the tape daily section. Even then, it cannot be warranted that all spores will be counted, especially if they occur in high numbers. Only if the full number of spores on the whole surface is known, it could be stated with certainty which of the considered methods gives a better estimation of fungal spore concentrations.

\section{DISCUSSION}

Both methods of calculation of Alternaria and Cladosporium spore concentrations used in this study revealed similar daily fluctuations on the same days, which indicated that both of them reflected reliably daily spore fluctuations. The differences, observed on days when one of the methods showed an increase or decrease in concentration which was not reflected by the other method, could be accepted as the result of uneven spore distribution on the tape. S t e r lin $\mathrm{g}$, Rogers and Levetin (1999) reported that daily spore concentration calculated by the 12 traverses method was usually higher than the concentration calculated by the 1 traverse method. These authors explain that particle deposition along and across the tape is uneven because of different spore size and wind velocity. At low wind velocity, large particles concentrate in the middle of the tape. At high wind velocity, particles seem to deposit more evenly (K ä p y lä and 
Penttinen, 1981). It can happen that, because of the irregular spore distribution, there occur two parallel zones of spore concentrations along the tape axis. In this situation, the concentration calculated by the 12 traverses method is often higher than the concentration calculated by the 1 traverse method. On the other hand, the study reported in Spain showed differences in number of particles among 4 horizontal traverses. The number of particles in 2 external traverses was about $7 \%$ lower than in 2 internal traverses, which gives the idea about the progressive decline of particle numbers from the centre to the longer edges of the tape (Molina, Rodriguez and Palacios, 1996). These conclusions support our results that spore concentration calculated by the 1 transverse method is usually higher than the concentration calculated by the 12 traverses method. These differences are statistically significant.

The results obtained by Ster $\mathrm{ling}$, R o ger s and Levetin (1999) in Oklahoma (USA) did not give an unequivocal answer to the question which method was more precise and reliable. Their study was performed at two sites. At the first site, the 12 traverses method showed a higher concentration than the 1 traverse method for Alternaria and Cladosporium spores. However, at the other site the higher concentration calculated by the 12 traverses method referred only to Cladosporium spores. The differences between the results obtained by Sterling, Rogers and Levetin (1999) and our results could have been caused by the different height at which the Burkard traps were located. In Oklahoma the trap was situated at $12 \mathrm{~m}$ and $1.3 \mathrm{~m}$, and in Cracow at $20 \mathrm{~m}$ above ground level. Usually the highest spore numbers are recorded at ground level or somehow higher ( $\mathrm{K} \mathrm{u} \mathrm{r}$ k ela, 1997). The studies performed at several sites in central and southern parts of Poland at different altitudes did not confirm this observation. The highest concentrations were noted at the highest levels: $34 \mathrm{~m}$ at Poznań and $36 \mathrm{~m}$ at Ostrowiec Świętokrzyski (S t ę p a l s k a et al. 1999). Also, the time of monitoring varied. In Oklahoma monitoring was carried out during one month (September) at the first site and one week (the beginning of September) at the second site. In Cracow 4 months (June, July, August and September) were analysed every year during 3 studied years. Another difference related to various magnifications applied in microscopic analysis. Sterling, Rogers and Levetin (1999) estimated average daily concentration at a magnification of $1000 \times$, in Cracow the magnification was $400 \times$.

In conclusion, the studies which have been performed hitherto and attempts to estimate the methods of spore concentration calculations do not allow us to indicate the most precise and reliable method.

\section{CONCLUSIONS}

1. Two different counting methods showed similar fluctuations of daily spore concentrations for Cladosporium and Alternaria on the same days.

2. Values of daily spore concentrations obtained using the 1 traverse method are generally higher than those obtained using the 12 traverses method.

3 . The correlation between higher daily concentrations obtained using the 12 traverses method and monthly total concentration is statistically significant at $\alpha=0.05$ for Cladosporium and non significant for Alternaria.

4. Differences between the two method values are significant for both Cladosporium and Alternaria at the significance level $\alpha=0.025$.

\section{Acknowledgments}

This study was supported by the project grant of the Ministry of Science and High Education No. 3 P04G 04922.

\section{REFERENCES}

A irborne pollens and spores. A guide to trapping and counting. The British Aerobiology Federation, 1994.

Carinanos P., Emberlin J., Galan C., DominguezVilches E., 2000. Comparison of two pollen counting methods of slides from a hirst type volumetric trap. Aerobiologia, 16: 339-346.

Comto is P., A lcazar P., Neron D., 1999. Pollen counts statistics and its relevance to precision. Aerobiologia, 15: $19-28$.

Hirst J. M., 1952. An automatic spore trap. Ann. Appl. Biol. 39: 257-265.

Käpylä M., Penttinen A., 1981. An evaluation of the microscopical counting methods of the tape in Hirst-Burkard pollen and spore trap. Grana, 20: 131-141.

Kurkela T., 1997. The number of Cladosporium conidia in the air in different weather conditions. Grana, 36: 54-61.

Molina R. T., Rodriguez A. M., Palacios I. S., 1996. Sampling in aerobiology. Differences between traverses along the length of the slide in Hirst spore trap. Aerobiologia, 12: 161-166.

Pessi A. M., 2003. Comparison of three microscopic counting methods for Burkard samples. [In:] Third European Symposium on Aerobiology, Abstracts: 27, Worcester, UK.

Sterling M., Rogers Ch., Levetin E., 1999. An evaluation of two methods used for microscopic analysis of airborne fungal spore concentrations from the Burkard spore trap. Aerobiologia, 15: 9-18.

Stępalska D., Harmata K., Kasprzyk I., Myszkow ska D., Stach A., 1999. Occurrence of airborne Cladosporium and Alternaria spores in Southern and Central Poland in 1995-1996. Aerobiologia, 15: 39-47. 


\section{Ocena koncentracji zarodników grzybów przy zastosowaniu dwóch metod liczenia}

\section{Streszczenie}

Celem pracy była ocena koncentracji zarodników Alternaria i Cladosporium przy zastosowaniu metody liczenia zarodników w 1 pasie horyzontalnym i w 12 pasach wertykalnych w preparacie mikroskopowym. Obydwie metody liczenia wykazały podobne wahania dobowych koncentracji obydwu typów zarodników w tych samych dniach, chociaż metoda liczenia w 1 pasie horyzontalnym wykazała wyższe koncentracje zarodników. Jednak analizując rozkład koncentracji uzyskanych dwoma metodami stwierdzono, że wystąpiły dni, kiedy metoda 1 pasa horyzontalnego lub 12 pasów wertykalnych wykazywała wzrost lub spadek koncentracji, czego nie odzwierciedlała druga z metod.
W przypadku Cladosporium wyższe dobowe koncentracje przy zastosowaniu metody 12 pasów wertykalnych występowały częściej w miesiącach o najwyższej koncentracji zarodników. Wyższe koncentracje zarodników Alternaria przy zastosowaniu tej samej metody występowały częściej w miesiącach o najniższej koncentracji zarodników. Analiza korelacji (współczynnik korelacji Pearson'a r) między tymi zmiennymi (liczbą dni z wyższą koncentracją a koncentracją miesięczną) wykazała, że istnieje istotna korelacja w przypadku Cladosporium i nieistotna w przypadku Alternaria na poziomie istotności $\alpha=0.05$. Wynik nie parametrycznego testu Wilcoxon'a wskazuje, że dla obydwu taksonów średnie dobowe koncentracje uzyskane za pomocą metody 1 pasa horyzontalnego są istotnie wyższe niż uzyskane za pomocą metody 12 pasów wertykalnych. 
